\title{
An assessment of serum acid and alkaline phosphatase determinations in prostatic cancer with a clinical validation of an acid phosphatase assay utilizing adenosine $3^{\prime}$-monophosphate as substrate ${ }^{1}$
}

\author{
DAVID M. GOLDBERG AND GRAHAM ELLIS \\ From the Department of Chemical Pathology, Royal Hospital, Sheffield
}

SYNOPSIS Serum acid phosphatase (AcPase) was measured by a colorimetric method utilizing adenosine $3^{\prime}$-monophosphate as substrate in 389 patients. In about half the cases blood was taken shortly after a rectal examination. The upper reference limit (mean + 2SD) for 116 cases with miscellaneous illness after eliminating outliers was $4 \cdot 1$ International Units per litre $(\mathrm{U} / \mathrm{I})$ at $37^{\circ} \mathrm{C}$, and no correlation existed between AcPase activity and age in these subjects $(r=0.040)$. Eight of 18 patients with untreated carcinoma confined within the prostate gland had AcPase activities below $4 \cdot 1 \mathrm{U} / \mathrm{l}$, and all of 27 cases with extension to pelvic soft tissues or to bone exceeded this value. AcPase activities above $4.1 \mathrm{U} / 1$ were found in $6 \%$ of cases with benign hypertrophy of the prostate, in $5 \%$ of cases with non-prostatic cancer, and in none of 22 cases with other urologica illness.

Raised serum alkaline phosphatase (APase) activity was found in $60 \%$ of patients with untreated prostatic cancer and in only $6 \%$ of patients free of prostatic cancer, in most of whom there was a clinical explanation for the elevation. The correlation between the two phosphatase activities was not significant $(\mathrm{r}=0.294)$. While APase activity does not reflect the stage of the disease as closely as AcPase activity, and is not so frequently elevated, it provided useful confirmation of the diagnosis in five patients of the present series whose AcPase levels were normal or only minimally elevated.

The value of serum acid phosphatase (AcPase, EC 3.1.3.2., orthophosphoric monoester phosphohydrolase) activity as an aid in the diagnosis of metastatic carcinoma of the prostate was first established by Gutman and his colleagues (Gutman and Gutman, 1938; Robinson, Gutman, and Gutman, 1939; Gutman, Gutman, and Robinson, 1940). The conclusions of these authors that raised values occur in about half the cases where metastases are to soft tissues only, and are uncommon when the tumour remains within the prostatic capsule, have been borne out by most authors who have subsequently reported their experience of large series of cases (Fishman, Bonner, and Homburger, 1956; Wood-

${ }^{1}$ A paper presented at the 90 th General Meeting of the Association of Clinical Pathologists, Cambridge, 5 April 1973

Received for publication 14 May 1973. ard, 1959; Veterans Administration Cooperative Urological Research Group, 1968; Murphy, Reynoso, Kenny, and Gaeta, 1969; Prout, 1969; Amador, Price, and Marshall, 1969).

The usefulness of AcPase estimations has been questioned by Marshall and Amador (1969) who made the point that no single case in their series was diagnosed on the basis of serum AcPase activity, since the diagnosis had already been made by the clinician before the results of those with raised levels were known. The older view concerning the value of serum AcPase measurements in following the progress of the disease, as summarized by Woodard (1959), has also been challenged (Schwartz, Greenberg, and Bodansky, 1963; Prout and Brewer, 1967). Consequently there is confusion and suspicion among many clinicians at the present time 
over the role of this enzyme in the diagnosis of cancer.

Recently, we introduced a new colorimetric assay for AcPase activity (Ellis, Belfield, and Goldberg, 1971). This utilizes as substrate adenosine 3'monophosphate which is rapidly hydrolysed by AcPase of human prostate, but poorly by AcPase of erythrocytes and other formed elements of the blood (Tsuboi and Hudson, 1953; 1955; Belfield and Goldberg, 1971). The object of this paper is to assess the diagnostic accuracy of this test based upon experience of a routine hospital service over a period of approximately 18 months.

\section{Materials and Methods}

\section{ENZYME METHODOLOGY}

Sera submitted to the laboratory with requests for AcPase determinations had this test performed by the colorimetric method of Ellis et al (1971) employing adenosine $3^{\prime}$-monophosphate (3'AMP) as substrate. Assays were carried out in duplicate by technical staff as part of the routine service of the laboratory, and were repeated if the values differed by more than $15 \%$. Results were expressed as International Units per litre at $37^{\circ} \mathrm{C}(\mathrm{U} / \mathrm{l})$. Quality control samples and standards were run with each batch and it was found necessary to repeat about one batch in 10 because of the rigorous criteria laid down for acceptability of results (all controls within mean $\pm 2 \mathrm{SD}$ and mean of all controls in batch within mean \pm 1 SD). Sera were separated with the minimum possible delay and kept at $4^{\circ} \mathrm{C}$, the assay being performed within 24 hours except at weekends. When sufficient serum was available, alkaline phosphatase (APase, EC 3.1.3.1.) activity was determined on the same sample by the method of Kind and King (1954) modified for use with the SMA 12/60 AutoAnalyzer (Technicon Instruments Co, Basingstoke, Hants); the normal range in our laboratory is 3-15 King Armstrong Units (KAU) per $100 \mathrm{ml}$.

CLASSIFICATION OF CASES

After completion of tests from 500 consecutive patients, a search was made of the relevant case notes with the object of classifying the patients into appropriate disease categories based upon the clinician's final diagnosis as communicated to the patient's general practitioner. Only 389 sets of notes could be located, the patients being allocated to the categories defined in table I.

\section{Prostatic cancer}

Those patients with untreated carcinoma of the prostate were further classified into four stages based upon the criteria of Murphy et al (1969) and defined as follows: Stage A (eight cases), a palpable prostatic nodule or unsuspected occult prostatic carcinoma discovered on transurethral resection or open operation; stage B (10 cases), a prostatic tumour, not nodular or occult, but confined to the prostatic gland; stage $C$ (seven cases), local extension to soft tissues round the prostate and within the pelvis; stage $D$ (21 cases), metastases to bone and/or soft tissues outside the pelvis.

Radiological abnormalities of spine and pelvis were, by definition, restricted to stage $D$ cases although all subjects had 'radiological and cystoscopic investigations performed. Within each of the above groups a distinction was made between those cases with histological proof of the diagnosis, and a larger number where the diagnosis was based exclusively upon clinical, radiological, and cystoscopic findings. Each patient was only included once even though his disease may have altered course over the period of investigation. In addition to the above cases presenting before treatment, a further 22 cases already under treatment with oestrogen therapy and/or orchidectomy at the time of the first AcPase assay by the new technique were included in this study.

\section{Benign hypertrophy of the prostate}

This group comprised 52 cases with histological proof of the diagnosis and 60 in whom the diagnosis rested exclusively on clinical and cystoscopic criteria. Some of the patients had associated prostatitis, and $25 \%$ had an intercurrent or unrelated chronic

\begin{tabular}{|c|c|c|c|c|}
\hline Group & No. of Cases & Mean Age (Years) & $S D$ & Range \\
\hline $\begin{array}{l}\text { Carcinoma prostate (untreated) } \\
\text { Carcinoma prostate (treated) } \\
\text { Benign hypertrophy of prostate (clinical) } \\
\text { Benign hypertrophy of prostate (biopsy) } \\
\text { Other cancers } \\
\text { Other urological illness } \\
\text { Miscellaneous } \\
\text { Undiagnosed }\end{array}$ & $\begin{array}{r}46 \\
22 \\
60 \\
52 \\
56 \\
22 \\
116 \\
15\end{array}$ & $\begin{array}{l}71 \cdot 0 \\
69 \cdot 8 \\
66 \cdot 9 \\
69 \cdot 0 \\
69 \cdot 6 \\
61 \cdot 0 \\
64 \cdot 4 \\
65 \cdot 3\end{array}$ & $\begin{array}{r}10 \cdot 8 \\
7 \cdot 9 \\
9 \cdot 1 \\
7 \cdot 3 \\
10 \cdot 2 \\
12 \cdot 4 \\
9 \cdot 7 \\
11 \cdot 1\end{array}$ & $\begin{array}{l}46-91 \\
58-83 \\
38-87 \\
54-87 \\
35-88 \\
35-77 \\
40-88 \\
45-83\end{array}$ \\
\hline
\end{tabular}

Table I Age distribution of patients studied 
illness such as a chest infection, hypertension, diabetes, or an episode of congestive cardiac failure.

\section{Other cancers}

This group comprised 56 cases with cancer of the following organs: bladder (14 cases); rectum (eight cases); bronchus (six cases); lung (five cases); breast (three cases); skin, colon, stomach, and pancreas (two cases each); others (12 cases).

\section{Other urological illness}

This group comprised 22 cases with the following conditions: urinary tract infection (seven cases); calculi (four cases); genital infections (four cases); chronic renal disease (four cases); congenital anomalies (three cases).

\section{Miscellaneous illness}

A total of 116 cases were placed in this category and included the following: cardiovascular disease (18 cases; hernia (16 cases); skeletal disorders (13 cases); gastrointestinal disease (13 cases); diabetes mellitus (eight cases); disorders of the central nervous system (eight cases); respiratory disease (seven cases); ear, nose, and throat conditions (four cases); others (four cases). A further 12 cases included in this category were ultimately considered free of organic disease. Fifteen cases with clear evidence of organic disease, some potentially involving the prostate gland, could not be allocated a definite diagnosis over the period of study and are included in a separate category.

\section{Results}

\section{EFFECT OF AGE}

As shown in table I, the age distributions within the various groups were similar. A regression analysis of AcPase with age was carried out on data for the miscellaneous group (fig 1). No correlation existed between the two $(r=0.040)$, consequently the normal range is unlikely to be dependent upon age.

\section{SUBJECTS FREE OF PROSTATIC CANCER}

The distribution of AcPase activities in the various groups excluding prostatic cancer is presented in

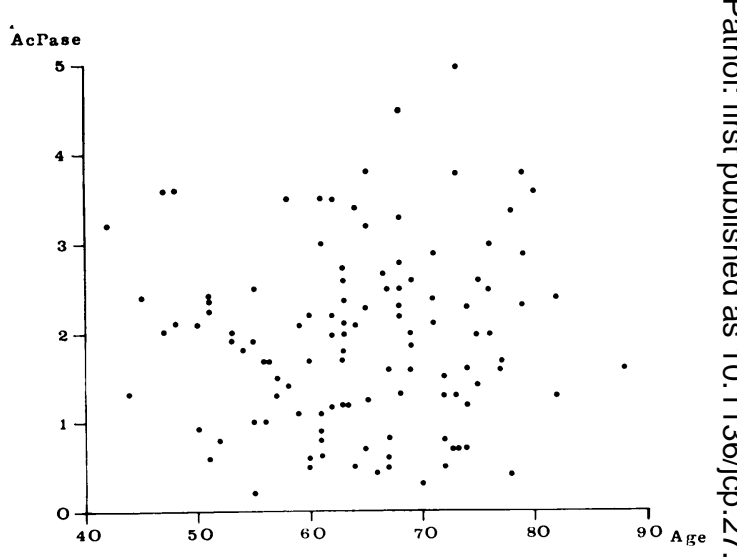

Fig 1 Plot of AcPase activity $\left(U / l\right.$ at $\left.37^{\circ} \mathrm{C}\right)$ against age (years) for 116 patients with miscellaneous illness.

figure 2. The mean and SD for each group were calculated, and recalculated excluding values outside the original mean +3 SD limit of $6 \cdot 1 \mathrm{U} / 1 \mathrm{ob}-\stackrel{2}{2}$ tained for the miscellaneous group. The overlap $\vec{\varphi}$ between the groups is obvious (table II), and the value of $4.1 \mathrm{U} / 1$ representing the recalculated mean $+2 \mathrm{SD}$ limit for the miscellaneous group seems am appropriate reference point to distinguish 'normat from 'abnormal' results. This value was exceeded in seven cases $(6 \%)$ of benign hypertrophy of the prostate; three cases $(5 \%)$ of other cancers; one case $(7 \%)$ in the undiagnosed group; and two $\vec{\circ}$ cases $(2 \%)$ in the miscellaneous group. The overall 3 'false-positive' rate was thus $4 \%$ of the 322 cases apparently free of prostatic cancer.

Clinical data on these 13 cases are presented in table III. The diagnosis in case 2 seems open to question, and in six other cases a catheter was in situ 3 at the time blood was drawn or a rectal examination had been carried out within a few hours.

SUBJECTS WITH PROSTATIC CANCER The distribution of AcPase activities in these patients $\frac{D}{O}$ according to the stage of the disease is shown in fig 3, which also separates the cases according to $N$

\begin{tabular}{|c|c|c|c|c|}
\hline Group & No. of Cases ${ }^{1}$ & Mean & $S D$ & Mean $+2 S D$ \\
\hline Benign hypertrophy of prostate (clinical) & 59 & 1.93 & 0.97 & $3 \cdot 87$ \\
\hline Benign hypertrophy of prostate (biopsy) & 50 & $2 \cdot 23$ & $1 \cdot 34$ & 4.91 \\
\hline Other cancers & 54 & $1 \cdot 87$ & 0.92 & $3 \cdot 71$ \\
\hline Other urological illness & 22 & $1 \cdot 55$ & 0.99 & $3 \cdot 53$ \\
\hline Miscellaneous & 115 & 1.97 & $1 \cdot 07$ & $4 \cdot 11$ \\
\hline Undiagnosed & 14 & $2 \cdot 10$ & 0.99 & $4 \cdot 08$ \\
\hline
\end{tabular}

Table II AcPase activities in groups other than prostatic cancer $(U / l)$

${ }^{1}$ All cases with activity $>6.1 \mathrm{U} / 1$ excluded. 

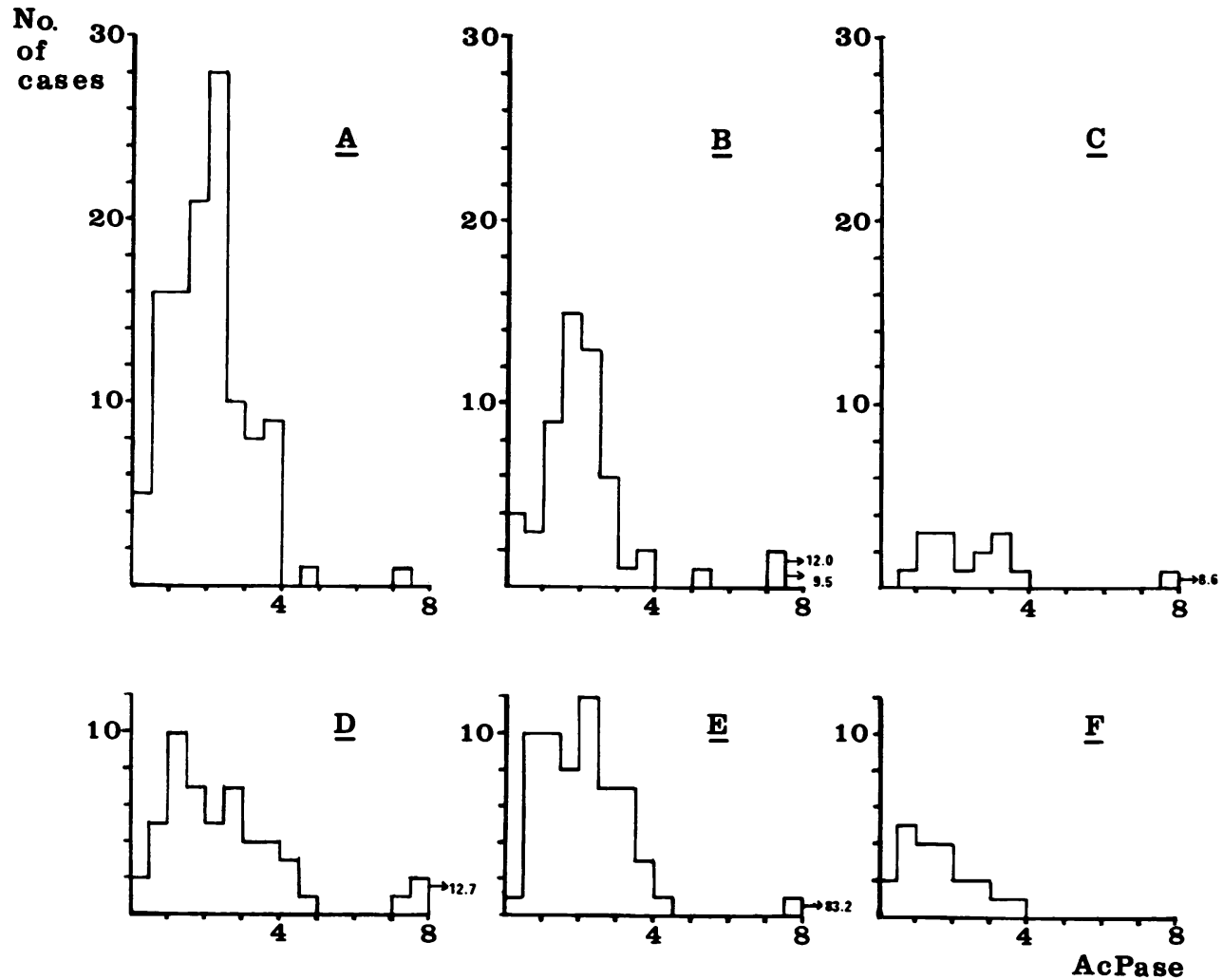

Fig 2 Distribution of AcPase activities $\left(U / l\right.$ at $\left.37^{\circ} \mathrm{C}\right)$ along horizontal axis in patients with disease other than prostatic cancer grouped as follows: $A$, miscellaneous; $B$, other cancers; $C$, undiagnosed; $D$, benign hypertrophy of prostate (biopsy); E, benign hypertrophy of prostate (clinical); $F$, other urological illness.

\begin{tabular}{|c|c|c|c|}
\hline Patient & Age & AcPase $(U / l)$ & Diagnosis \\
\hline $\begin{array}{r}1 \\
2 \\
3 \\
4 \\
5 \\
6 \\
7 \\
8 \\
9 \\
10 \\
11 \\
12 \\
13\end{array}$ & $\begin{array}{l}69 \\
70 \\
81 \\
74 \\
70 \\
75 \\
80 \\
72 \\
78 \\
68 \\
73 \\
74 \\
78\end{array}$ & $\begin{array}{r}4 \cdot 2 \\
83 \cdot 2 \\
4 \cdot 3 \\
4 \cdot 7 \\
7 \cdot 2 \\
7 \cdot 8 \\
12 \cdot 7 \\
5 \cdot 2 \\
9 \cdot 5 \\
4 \cdot 5 \\
7 \cdot 5 \\
7 \cdot 3 \\
8 \cdot 6 \\
12 \cdot 0\end{array}$ & $\begin{array}{l}\text { Benign hypertrophy of prostate (clinical) } \\
\text { Benign hypertrophy of prostate (clinical). Died before further study } \\
\text { Benign hypertrophy of prostate (biopsy) } \\
\text { Benign hypertrophy of prostate (biopsy) } \\
\text { Benign hypertrophy of prostate (biopsy) } \\
\text { Benign hypertrophy of prostate (biopsy) } \\
\text { Benign hypertrophy of prostate (biopsy) } \\
\text { Chronic myeloid leukaemia } \\
\text { Carcinoma larynx, AcPase fell to } 2 \cdot 1 \text { on stilboestrol } \\
\text { Pneumonia, nodular prostate } \\
\text { Extensive Paget's disease } \\
\text { Undiagnosed, prostate enlarged and irregular } \\
\text { Carcinoma bladder }{ }^{2}\end{array}$ \\
\hline
\end{tabular}

Table III Patients with raised AcPase ( $>4 \cdot 1 \mathrm{U} / \mathrm{I})$ with diagnosis other than prostatic cancer

${ }^{1}$ Rectal examination within 24 hours of blood sample.

'Bladder catheter in situ at the time of sample.

whether histological proof of diagnosis was or was not obtained. This confirmation applied to a minority of the subjects, but the distribution of values within each stage was independent of this consideration and there is no evidence that inclusion of patients lacking histological confirmation decreased the incidence of raised AcPase activities.

The level of AcPase activity in the treated subjects seemed to reflect the balance between control and activity of the disease process, most of those with 


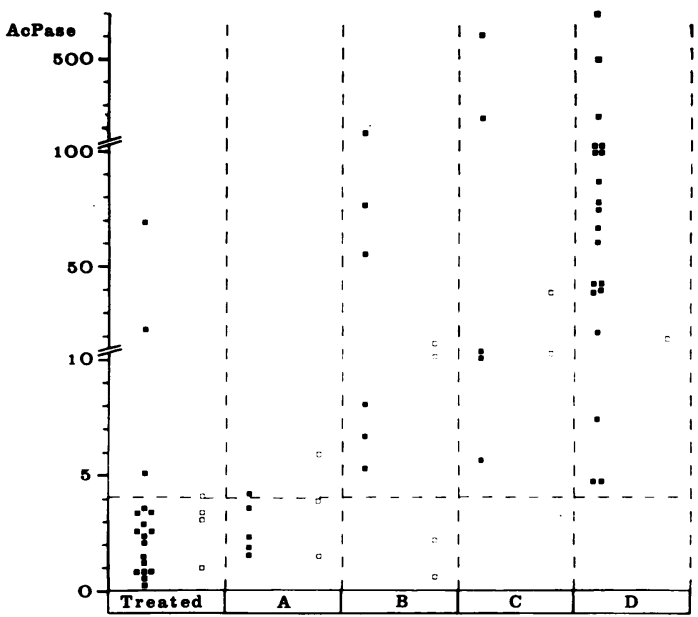

Fig 3 Distribution of AcPase activities $\left(\mathrm{U} / \mathrm{l}\right.$ at $\left.37^{\circ} \mathrm{C}\right)$ along vertical axis in patients with prostatic cancer grouped according to the stage of the disease (see text). Open symbols indicate patients with histological proof of diagnosis and solid symbols patients lacking such confirmation.

values $<4.1 \mathrm{U} / 1$ being symptom-free at the time of the test; the two highest values came from patients with widespread uncontrolled disease approaching the terminal phase. The values in cases presenting for the first time bore a clear relation to the stage of the disease, all cases in stages $\mathrm{C}$ and $\mathrm{D}$ having raised AcPase activities as compared with $80 \%$ of stage B cases and $25 \%$ of stage A cases. These elevations were slight in a proportion of cases and there was considerable overlap between the values in stage $C$ and $D$ subjects and those with stage $A$ or B disease.

\section{ALKALINE PHOSPHATASE RESULTS}

Figure 4 compares results of both serum phosphatase activities in those 43 patients with untreated prostatic cancer where both were determined. The correlation between them was not significant $(r=0 \cdot 290)$, and APase did not reflect the stage of the disease, normal values being found in three stage D cases. Elevated APase activities occurred in the presence of normal $\overrightarrow{\vec{F}}$ AcPase activities in three cases with stage $\mathrm{A}$ or $-\overrightarrow{0}$ stage B disease. Two further cases had AcPase activities between $4 \cdot 1$ and $6.0 \mathrm{U} / 1$ and APase $\overline{\bar{c}}$. activities in excess of $50 \mathrm{U} / 1$.

The overall incidence of raised serum APase activity in patients with untreated prostatic cancer ${ }^{\infty}$ was $60 \%$. This contrasts with an overall incidence $\vec{O}$ of $6 \%$ in patients free of prostatic cancer in whom $\overrightarrow{ }$ this investigation was performed. Table IV analyses ${ }_{\sigma}^{\omega}$ this incidence for the various groups and indicates $\widehat{\widehat{O}}$ the proportion of elevations for which a clinical i explanation could be adduced as, for example, when $y$ Paget's disease of bone, malabsorption, deranged $\stackrel{N}{-}$ metabolism of calcium or phosphate as indicated by $\overrightarrow{\vec{O}}$ abnormal serum levels of either, osseous metastaseso from non-prostatic cancers, or renal osteodystrophy were present.

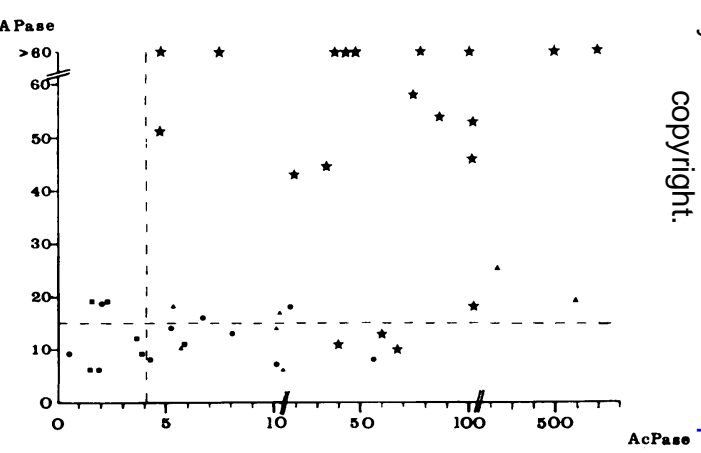

Fig 4 Comparison of alkaline phosphatase (APase) activity as KAU per $100 \mathrm{ml}$ with AcPase activity $\left(U / l\right.$ at $37^{\circ} \mathrm{C}$ ) in patients with untreated prostatic cancer grouped as follows: squares, stage $A$; circles, stage $B$; triangles, stage $C$; stars, stage $D$ (for staging, see text). Upper normal limits for each enzyme indicated by broken lines.

\begin{tabular}{|c|c|c|c|c|c|}
\hline \multirow[t]{2}{*}{ Group } & \multirow{2}{*}{$\begin{array}{l}\text { No. of Subjects } \\
\text { Serum APase } \\
\text { Estimated }\end{array}$} & \multicolumn{4}{|c|}{ No. of Subjects in Various Activity Ranges $(K A U / 100 \mathrm{ml})$} \\
\hline & & $<16$ & $16-25$ & $26-50$ & $>50$ \\
\hline Benign hypertrophy of prostate (clinical) & 50 & 46 & $2(1)$ & $1(1)$ & $1(1)$ \\
\hline Benign hypertrophy of prostate (biopsy) & 41 & 39 & 1 & 1 (1) & 0 \\
\hline Other cancers & 51 & 46 & $2(1)$ & $2(1)$ & $1(1)$ \\
\hline Other urological illness & 20 & 18 & 1 (1) & 1 (1) & 0 \\
\hline Miscellaneous & 72 & 70 & 1 & 0 & 1 (1) \\
\hline Undiagnosed & 8 & 8 & 0 & 0 & 0 \\
\hline Total & 242 & 227 & 7 (3) & 5 (4) & $3(3)$ \\
\hline
\end{tabular}

Table IV Incidence of raised serum alkaline phosphatase activities in groups other than prostatic cancer

The open figures represent total numbers in each range for each category. Figures in parenthesis represent that number of the total for whom a $\overparen{D}$ clinical explanation of the elevation could be adduced (see text). 


\section{Discussion}

Bodansky and Bodansky (1952) reviewed the literature up to that point in time and reported an incidence of raised serum AcPase activity in $81 \%$ of 349 cases with bone metastases and in $24 \%$ of 218 cases without bone metastases. A more recent review (Bodansky, 1972) supports this incidence of AcPase elevations in the two groups. Table $\mathrm{V}$ compares the incidence of abnormal values in our untreated cases with those reported in some large representative series grouped, in so far as possible, into the same four stages. The diagnostic accuracy of the present assay appears superior, although the number of cases is smaller than in those series with which the data are compared, and two of the 21 stage D cases had levels barely above the normal range.

It is not clear why this should be so. Superiority of current diagnostic procedures is unlikely to be a factor since biopsy confirmation was lacking in the majority of cases. Improved specificity of $3^{\prime}$ AMP for the prostatic enzyme can only have played a minor role since beta-glycerophosphate (Woodard, 1959; Bodansky, 1972) and alpha-naphthyl phosphate (Babson and Read, 1959; Babson, Read, and Phillips, 1959) are probably just as 'specific'-an adjective which in this situation is somewhat misleading, since all three substrates are hydrolysed by AcPases present in most organs and tissues (Hollander, 1971). Similar reservations apply to the use of tartratelabile AcPase assays, introduced by Abul-Fadl and King (1949) and popularized by Fishman and Lerner (1953) as a means of estimating prostatic AcPase in serum. Claims for the superiority of this assay as a diagnostic procedure for prostatic cancer (Fishman et al, 1956) have not been substantiated (Murphy et $a l, 1969$ ), and absence of the prostate appears to make no difference to the activity of this enzyme in serum (Dow and Whitaker, 1970).

It is clear that the distribution of cases among the various histological types will profoundly influence the incidence of raised serum AcPase levels at each stage of the disease, since well differentiated tumours are rich in the enzyme and anaplastic tumours may have greatly reduced concentrations (Mobley and Frank, 1968). Unfortunately, we do not know the true incidence of anaplastic tumours in this series because of failure to carry out histological examinations and, even if we did, the information on this topic provided by the authors of some of the reports documented in table $\mathrm{V}$ are not sufficiently detailed to permit accurate assessment of the comparative incidence of various tumour types.

In view of the appallingly poor performance of AcPase assays in general laboratories (Copeland and Vanderlinde, 1972), which must have coloured clinicians' appreciation of the test and probably influenced the data of earlier series (table V), it seems quite possible that rigorous attention to quality control and a high standard of technical skill in an enzyme-orientated laboratory were the main factors contributing to the satisfactory results in this series.

One other factor merits consideration: the role of prostatic massage on serum AcPase levels. Six of the 13 cases without prostatic cancer but with raised serum AcPase activities had rectal examination performed within two hours of the blood being drawn or were catheterized at that time. By inducing infarction of an enlarged prostate, catheterization may lead to gross transient elevations of serum AcPase (Howard and Fraley, 1965). Hock and Tessier (1949) reported elevation of the serum AcPase above the initial value in 17 of 20 patients undergoing rectal examination. In three out of 24 patients with benign cystic hypertrophy, significant elevation of serum AcPase activity occurred after rectal examination, probably as a consequence of rupture of cysts releasing enzyme-rich secretion into the blood (Daniel and Van Zyl, 1952). Elevations were also reported under similar circumstances in some patients with prostatic cancer (Bonner, Homburger, and Fishman, 1954), and as a common sequel to handling of the prostate during transvesical enucleation of the gland (Romslo, 1971). Other authors have been unable to detect any significant

\begin{tabular}{|c|c|c|c|c|c|c|}
\hline Reference & $\begin{array}{l}\text { Sullivan et al } \\
\text { (1942) }\end{array}$ & $\begin{array}{l}\text { Herbert } \\
(1946)\end{array}$ & $\begin{array}{l}\text { Woodard } \\
\text { (1952) }\end{array}$ & $\begin{array}{l}\text { Marshall and Amador } \\
\text { (1969) }\end{array}$ & $\begin{array}{l}\text { Murphy et al } \\
\text { (1969) }\end{array}$ & $\begin{array}{l}\text { Present } \\
\text { Series }\end{array}$ \\
\hline $\begin{array}{l}\text { Total no. of cases } \\
\text { Substrate }\end{array}$ & \multicolumn{2}{|c|}{$\begin{array}{l}200 \\
\text { Phenyl phosphate }\end{array}$} & \multicolumn{3}{|c|}{ Beta-glycerophosphate } & $\begin{array}{l}46 \\
3^{\prime} A M P\end{array}$ \\
\hline $\begin{aligned} & \text { Stage } \text { A } \\
& \text { B } \\
& \text { C } \\
& \text { D }\end{aligned}$ & \}$_{85} 11$ & \}$_{89} 42$ & \}$_{60} 25$ & \}$_{56} 46$ & $\begin{array}{l}45 \\
36 \\
57 \\
88\end{array}$ & $\begin{array}{r}25 \\
80 \\
100 \\
100\end{array}$ \\
\hline All stages & 59 & 62 & 65 & 56 & 64 & 83 \\
\hline
\end{tabular}

Table V Incidence ( $\%$ ) of AcPase elevation in prostatic cancer 
change in serum AcPase levels after rectal examination (Marshall and Amador, 1969; Christensen and Nielsen, 1972).

The situation is therefore controversial, but it seems that elevations may occur in some patients depending on the vigour of palpation and the type of lesion present in the prostate, and the level may rise above normal limits if the basal values were already tending towards the upper range. That this was a factor in the six patients referred to is evidenced by the fact that, in four who had the test repeated, normal values were found. The custom of our clinical colleagues was such that rectal examination was carried out shortly before venepuncture on approximately half the cases in this series including cases with and without prostatic cancer in similar proportions. This practise could conceivably lead to a higher incidence of raised values in cases with prostatic cancer than would otherwise be found. Such a hypothesis is difficult to substantiate or disprove, since the incidence of rectal examination was similar in prostatic cancer patients with and without raised AcPase values, and subsequent normalization of values could in all instances have been due to the effect of therapy rather than to adventitial elevations when the test was first performed.

However certain indirect evidence enables us to exclude rectal examination as exercising a major influence. Of the six patients with normal AcPase values and stage $\mathrm{A}$ disease, the blood was drawn before rectal examination in three and after in the other three. Of the eight patients with raised AcPase values and stage $B$ disease, an equal number had blood drawn before and after rectal examination. Only two of the cases with stage $C$ disease and nine of the cases with stage $\mathrm{D}$ disease had blood drawn after rectal examination, yet $100 \%$ of cases in both categories had raised AcPase values. Furthermore, blood was drawn before and 90-120 minutes after rectal examination in 10 cases of prostatic cancer after the rest of this study had been completed to assess the probable influence of this procedure upon serum AcPase activity in similar cases in this series. In three cases the activity rose, in five cases activity fell, and in two was unchanged after rectal examination, the mean change being $+0.6 \mathrm{U} / \mathrm{l}$. None of the five cases with normal activity (three treated and two untreated) yielded an abnormal value as a consequence of this intervention.

Elevation of serum APase activity was less frequent than that of AcPase activity, even in subjects with stage $D$ disease. This is contrary to the experience of other authors who have reported a higher incidence of raised APase activity in patients with osseous prostatic metastases (Nesbit and Baum, 1951; Woodard, 1953, 1959), although, as pointed out by Gutman (1959), such elevations lack the specificity for the disease attributable to raised AcPase activities and are less immediately respon- $\frac{}{-}$ sive to successful therapy. In view of the occurrence $\overrightarrow{\vec{D}}$ of raised APase activities in many subjects of the present series with no objective evidence of skeletal $\frac{}{0}$ metastases and even in some with normal or mini- $\overline{\frac{D}{D}}$ mally elevated AcPase levels, the assay clearly is of $\vec{\nabla}$ value as a confirmatory test. The basis of such 응 elevations is far from clear; conceivably they could के arise as a consequence of unrecognized skeletal $\overrightarrow{0}$ metastases, implying that the incidence of stage $\mathrm{D} \overrightarrow{\vec{H}}$ cases has been underestimated in this series and that, $\vec{\omega}$ consequently, the occurrence of raised AcPase values in patients without such metastases has been over-? estimated.

The value of $4 \cdot 1 \mathrm{U} / 1$ suggested as the reference $\mathrm{iv}$ limit for this AcPase assay appears to serve as a $\overrightarrow{\vec{A}}$ good discriminant, the overall incidence of 'falsepositive' elevations being lower than in almost all the major reports reviewed by Bodansky (1972). $\vec{T}$ Failure to find an association between serum AcPase $\mathbb{D}$ and age is in accord with previous results (Day, Ying, Schwartz, Whitmore, and Bodansky, 1956; 芝 Ericksson, Ginsburg, Hultberg, and Öckerman, 1972). In our hands the assay has given clinically useful results and appears to justify its inclusion the routine investigtion of prostatic disease and ever. in males with non-specific 'backache'. Consideratio of the curious circumstances surrounding cases $\overrightarrow{2}$ and 9 (table III) and of the fact that two of the stage $D$ cases had been treated at a rheumatic clinic for some months before the diagnosis was made, suggests that those clinicians who ignore the value of AcPase determinations do so at the peril of some, at least, of their patients.

We are grateful to the technical staff of the Department of Chemical Pathology, Royal Hospital, Sheffield, for their skilled assistance, and to the physicians and surgeons of the United Sheffield Hospitals who granted access to their case records. In particular, we are indebted to $\mathrm{Mr} \mathrm{J}$. L. Williams, FRCS, and to Mr M. Fox, FRCS.

\section{References}

Abul-Fadl, M. A. M., and King, E. J. (1949). Properties of the acid O phosphatases of erythrocytes and of the human prostate gland. Biochem. J., 45, 51-60.

Amador, E., Price, J. W., and Marshall, G. (1969). Serum acid N a-naphthyl phosphatase activity. Amer. J. clin. Path., 51, 202206.

Babson, A. L., and Read, P. A. (1959). A new assay for prostatic acid phosphatase in serum. Amer. J. clin. Path., 32, 88-91.

Babson, A. L., Read, P. A., and Phillips, G. E. (1959). The importance of the substrate in assays of acid phosphatase in serum. Amer. क J. clin. Path., 32, 83-87.

Belfield, A., and Goldberg, D. M. (1971). Hydrolysis of adenosine monophosphates by acid phosphatases as measured by a continuous spectrophotometric assay. Biochem. Med., 4, 135148 . 
Bodansky, M., and Bodansky, O. (1952). Biochemistry of Disease, 2nd ed., p. 1179. Macmillan, New York.

Bodansky, O. (1972). Acid phosphatase. Advanc. clin. Chem., 15, 43-147.

Bonner, C. D., Homburger, F., and Fishman, W. H. (1954). Some factors other than neoplasms altering the prostatic fraction of acid phosphatase in the serum. Surg. Gynec. Obstet., 99, 179183.

Christensen, P., and Nielsen, M. L. (1972). Serum acid phosphatase: the influence of routine rectal examination with diagnostic palpation of the prostate. Scand. J. Urol. Nephrol., 6, 103-106.

Copeland, W. H., and Vanderlinde, R. E. (1972). Determination of serum acid phosphatase activity: a performance evaluation for clinical laboratories of upstate New York. Clin. Chem., 18, 131-136.

Daniel, O., and Van Zyl, J. J. (1952). Rise of serum-acid-phosphatase level following palpation of the prostate. Lancet, 1, 998-999.

Day, E., Ying, S. H., Schwartz, M. K., Whitmore, W. F., Jr., and Bodansky, O. (1956). Serum prostatic acid-phosphatase levels in the male patients of a cancer-prevention clinic. Cancer (Philad.), 9, 222-227.

Dow, D., and Whitaker, R. H. (1970). Prostatic contribution to normal serum acid phosphatase. Brit. med. J., 4, 470-472.

Ellis, G., Belfield, A., and Goldberg, D. M. (1971). Colorimetric determination of serum acid phosphatase activity using adenosine 3'-monophosphate as substrate. J. clin. Path., 24, 493-500.

Eriksson, Ö., Ginsburg, B. E., Hultberg, B., and Öckerman, P. A. (1972). Influence of age and sex on plasma acid hydrolases. Clin. chim. Acta, 40, 181-185.

Fishman, W. H., Bonner, C. D., and Homburger, F. (1956). Serum 'prostatic' acid phosphatase and cancer of the prostate. New Engl. J. Med., 255, 925-933.

Fishman, W. H., and Lerner, F. (1953). A method for estimating serum acid phosphatase of prostatic origin. J. biol. Chem., 200, 89-97.

Gutman, A. B. (1959). Serum alkaline phosphatase activity in diseases of the skeletal and hepatobiliary systems: a consideration of the current status. Amer. J. Med., 27, 875-901.

Gutman, A. B., and Gutman, E. B. (1938). An 'acid' phosphatase occurring in the serum of patients with metastasizing carcinoma of the prostate gland. J. clin. Invest., 17, 473-478.

Gutman, A. B., Gutman, E. B., and Robinson, J. N. (1940). Determination of serum 'acid' phosphatase activity in differentiating skeletal metastases secondary to prostatic carcinoma from Paget's disease of bone. Amer. J. Cancer, 38, 103-108.

Herbert, F. K. (1946). The estimation of prostatic phosphatase in serum and its use in the diagnosis of prostatic carcinoma. Quart. J. Med., 15, 221-241.

Hock, E., and Tessier, R. N. (1949). Elevation of serum acid phosphatase following prostatic massage. J. Urol., 62, 488-491.

Hollander, V. P. (1971). Acid phosphatases. In The Enzymes, edited by P. D. Boyer, 3rd ed., vol. 4, pp. 449-498. Academic Press, New York.
Howard, P. J., Jr., and Fraley, E. E. (1965). Elevation of the acid phosphatase in benign prostatic disease. J. Urol., 94, 687-690.

Kind, P. R. N., and King, E. J. (1954). Estimation of plasma phosphatase by determination of hydrolysed phenol with aminoantipyrine. J. clin. Path., 7, 322-326.

Marshall, G., and Amador, E. (1969). Diagnostic usefulness of serum acid $\beta$-glycerophosphatase activities in prostatic disease. Amer. J. clin. Path., 51, 551-554.

Mobley, T. L., and Frank, I. N. (1968). Influence of tumor grade on survival and on serum acid phosphatase levels in metastatic carcinoma of the prostate. J. Urol., 99, 321-323.

Murphy, G. P., Reynoso, G., Kenny, G. M., and Gaeta, J. F. (1969). Comparison of total and prostatic fraction serum acid phosphatase levels in patients with differentiated and undifferentiated prostatic carcinoma. Cancer (Philad.), 23, 1309-1314.

Nesbit, R. M., and Baum, W. C. (1951). Serum phosphatase determinations in diagnosis of prostatic cancer; a review of 1150 cases. J. Amer. med. Ass., 145, 1321-1324.

Prout, G. R., Jr. (1969). Chemical tests in the diagnosis of prostatic carcinoma. J. Amer. med. Ass., 209, 1699-1670.

Prout, G. R., Jr., and Brewer, W. R. (1967). Response of men with advanced prostatic carcinoma to exogenous administration of testosterone. Cancer (Philad.), 20, 1871-1878.

Robinson, J. N., Gutman, E. B., and Gutman, A. B. (1939). Clinical significance of increased serum 'acid' phosphatase in patients with bone metastases secondary to prostatic carcinoma. J. Urol., 42, 602-618.

Romslo, I. (1971). The effect of prostatic surgery on the acid phosphatase level. Scand. J. Urol. Nephrol., 5, 111-115.

Schwartz, M. K., Greenberg, E., and Bodansky, O. (1963). Comparative values of phosphatases and other serum enzymes in following patients with prostatic carcinoma: consideration of phosphohexose isomerase, glutamic oxalacetic transaminase, isocitric dehydrogenase, and acid and alkaline phosphatases. Cancer (Philad.), 16, 583-594.

Sullivan, T. J., Gutman, E. B., and Gutman, A. B. (1942). Theory and application of the serum 'acid' phosphatase determination in metastasizing prostatic carcinoma; early effects of castration. J. Urol., 48, 426-458.

Tsuboi, K. K., and Hudson, P. B. (1953). Acid phosphatase. I. Human red cell phosphomonoesterase; general properties. Arch. Biochem., 13, 339-357.

Tsuboi, K. K., and Hudson, P. B. (1955). Acid phosphatase. III. Specific kinetic properties of highly purified human prostatic phosphomonoesterase. Arch. Biochem., 55, 191-205.

Veterans Administration Cooperative Urological Research Group (1968). Factors in the prognosis of carcinoma of the prostate: a cooperative study. J. Urol., 100, 59-65.

Woodard, H. Q. (1952). Factors leading to elevations in serum acid glycerophosphatase. Cancer (Philad.), 5, 236-241.

Woodard, H. Q. (1953). Changes in blood chemistry associated with carcinoma metastatic to bone. Cancer (Philad.), 6, 1219-1227.

Woodard, H. Q. (1959). The clinical significance of serum acid phosphatase. Amer. J. Med., 27 902-910. 